УДК 785+792+78.071.1(477)«19»

Антон Вадимович Олендарьов,

здобувач кафедри теорії музики

Національної музичної академії імені П. І. Чайковського

odma_n@ukr.net

\title{
КОМПОЗИТОРСЬКІ ІНСТРУМЕНТАЛЬНІ СТИЛІ В МУЗИЦІ ДО ДРАМАТИЧНИХ ВИСТАВ (НА ПРИКЛАДІ ТВОРЧОСТІ ВІТЧИЗНЯНИХ КОМПОЗИТОРІВ ДРУГОЇ ПОЛОВИНИ ХХ СТ.)
}

Метою статті є встановлення закономірностей інструментального мислення I. Шамо, В. Рождественського, М. Скорика в музиці до драматичних вистав. Методологія: у статті застосовано аналітичний, жанровий, інтонаційний, стильовий та системний підходи. Наукова новизна: у статті вивчаються особливості інструментальних стилів провідних вітчизняних композиторів ХХ ст. - В. Рождественського, I. Шамо, М. Скорика - вконтексті музики до драматичних вистав. Висновки: на основі зробленого аналізу можна стверджувати, що ці композитори проявили себе як майстри з чітко визначеним власними інструментальними стилями. Стрижнем цього слід вважати постійне намагання індивідуалізувати, перш за все, виконавський склад. Базою для того виступає великий симфонічний оркестр парного складу, «адаптований» для потреб і можлливостей драматичного театру.

Ключові слова: театр, музика, оркестр, інструментарій, інструментальний стиль, українські композитори.

Olendarev Anton, applicant of the department of theory of music, National P. I. Tchaikovsky Academy of Music

Instrumental music styles to drama performances (basis on creative work of native composers second half $X X$ century)

The purpose of article is identification of regularities of tool thinking of I. Shamo, V. Rozhdestvensky, M. Skorik in music to drama performances. Methodology: in article analytical, genre, intonational, style and system approaches are applied. Scientific novelty: in article features of instrumental styles of the leading domestic composers of the 20th century - V. Rozhdestvensky, I. Shamo, M. Skorik - in the context of music to drama performances are studied. Conclusions: on the basis of the made analysis it is possible to claim that these composers have proved as masters with accurately defined own instrumental styles. The core of it should be considered the constant aspiration to individualize, first of all, performing structure. As base the big symphonic orchestra of pair structure «adapted» for requirements and opportunities of drama theater for this purpose acts.

Keywords: theatre, music, orchestra, instrumental, instrumental style, Ukrainian composers. 
Олендарев Антон Вадимович, соискатель кафедры теории музыки Национальной музыкальной академии Украины имени П. И. Чайковского

Инструментальные композиторские стили в музыке к драматическим спектаклям (на примере творчества отечественных композиторов второй половины $X X$ в.)

Целью статьи является выявление закономерностей инструментального мышления И. Шамо, В. Рождественского, М. Скорика в музыке $\kappa$ драматическим спектаклям. Методология: в статье применены аналитический, жанровый, интонационный, стилевой и системный подходы. Научная новизна: в статье изучаются особенности инструментальных стилей ведущих отечественных композиторов ХХ в. - В. Рождественского, И. Шамо, М. Скорика - в контексте музыки к драматическим спектаклям. Выводы: на основе сделанного анализа можно утверждать, что эти композиторы проявили себя как мастера с четко определившимися собственными инструментальными стилями. Стержнем этого следует считать постоянное стремление индивидуализировать, прежде всего, исполнительский состав. Базой для этого выступает большой симфонический оркестр парного состава, «адаптированный» для потребностей и возможностей драматического театра.

Ключевые слова: театр, музыка, оркестр, инструментарий, инструментальный стиль, украинские композиторы.

Актуальність статті. Український драматичний театр другої половини XX ст. уявляв собою різнобарвне явище. Не в останню чергу цьому сприяв факт наявності, так би мовити, «живого» музичного оформлення в більшості вистав. Згідно з довідниками Спілки композиторів УСРС більше половини тогочасних авторів співпрацювали з драматичним театром. Серед них пригадуються такі творчі особистості, як Г. Майборода, П. Майборода, Б. Лятошинський, М. Вериківський та ін. Тому на сьогоднішній день в полі зору мистецтвознавців досить часто опиняються питання, пов’язані з музичною складовою в драматичному театрі.

Так, наприклад, такі експерти в цій галузі, як О. Вергеліс, О. Красильникова, Н. Кузякіна, Ю. Станішевський, Г. Скрипник та ін., звертаються до проблематики музичного оформлення драматичних вистав, але в загальному плані, тобто без конкретного аналізу інструментального аспекту $[1 ; 4 ; 5 ; 8 ; 9]$. А в середині XX ст. відомий радянський мистецтвознавець А. Глумов не тільки звертався до цілісного обзору музичного оформлення сценічного дійства, але й акцентував увагу на необхідності вивчення інструментарію [2].

Об'єктом дослідження в рамках даної статті обрана музична складова драматичної вистави. Предметом, таким чином, являються осо- 
бливості інструментального стилю в театральній музиці I. Шамо, В. Рождественського, М. Скорика.

Метою статті $є$ встановлення закономірностей інструментального мислення кожного з представлених авторів саме в музиці до драматичних вистав.

Вибір для розгляду творчого надбання саме цих композиторів викликаний наступними чинниками. В. Рождественський все своє професійне життя присвятив композиторській діяльності в драматичному театрі, а саме - на посаді музичного керівника театру ім. І. Франка. В творчому доробку I. Шамо також знаходяться досить цікаві приклади його співпраці з вищеназваним жанром. Постать М. Скорика привертає увагу тим, що з його появою на теренах драматичного мистецтва почалися суттєві зміни в принципах підбору інструментарію.

Виклад основного матеріалу. Розгляд вищеназваної теми почнемо 3 постаті В. Рождественського. Він - диригент, композитор та аранжувальник. Очолював музичну частину театру близько 40 років. Завдяки йому на тогочасній франківській сцені, окрім звичного мелодраматичного жанру, була також поширена музична комедія. Прикладами являються: «Пісня про вірну любов» К. Плоткина, «За двома зайцями» Б. Олійника, «Черевички» В. Васильки, «Жайворонки» М. Горіна. Окрім цього, за значимістю ролі музики, до щойно названих творів наближаються такі вистави, як «Мертвий Бог» М. Зарудного, «Мілана» О. Турчинського, «На хуторі близь Диканьки» В. Минка, «Над Дніпром» Б. Корнійчука, «Пророк» I. Кочерги [7]. Переважна більшість цих праць отримала визнання як з боку експертів-професіоналів, так й широкої глядацької аудиторії. Дійсно професійне знання В. Рождественського технічних можливостей оркестрового інструментарію сприяло глибокому проникненню в різноманітну жанрову стилістику. Свідченням тому можуть виступати його рівноцінно якісні роботи як в перлинах української класики («Майська ніч»), так і в творах російського колориту («Старим козачім способом») та в дусі зарубіжної опереткової класики («Кроків’яни та гуралі»). Творчу постать даного композитора вигідно відрізняло не тільки вміння подати власний матеріал, але й адекватно відобразити стилістичну специфіку музики колег по композиторському цеху під час виступів в якості диригента.

У свою чергу, серед українських композиторів XX ст. помітною постаттю був й І. Шамо. Діапазон його творчої спадщини надзвичайно широкий - від кантат («Співає Україна» на вірші Д. Луценко; «Ле- 
нін» на слова В. Маяковського), симфонічних творів («Фестивальна сюїта», «Молдавська поема-рапсодія»), камерно-інструментальних творів (4 квартети для струнних) до кіномузики («Як закалялась сталь», «Матрос Чижик», «Мальва», «Командир корабля») і окремих естрадних пісень («Осіннє золото», «Києве мій») [7].

Особливе місце в його творчості належить театральній музиці. На перший погляд, вистав з музикою I. Шамо небагато, але вони дають досить чітке уявлення про широту інтересів цього композитора у цій сфері - від драматургії минулого до сучасних п’єс, від зарубіжної до вітчизняної класики. Йдеться про «Макбет» В. Шекспіра, «Безталанна» П. Карпенка-Карого, «У неділю рано зілля копала» О. Кобилянської, «Правда» та «Сторінка щоденника» А. Корнійчука, «Горлиця» та «Голубі олені» А. Коломійця, «Кар'єра Бекетова» А. Софронова [6; 7]. Ці вистави стали помітною подією в житті провідних українських театрів - київських ім. І. Франка та ім. Лесі Українки, Чернівецького музично-драматичного театру ім. О. Кобилянської.

М. Скорик являється одним з найвідоміших сучасних українських композиторів. Палітра його творчого доробку охоплює різноманітні жанри: від інструментальних концертів для скрипки, фортепіано, симфонічних творів до досить екзотичних «прецедентів», таких як «24 каприси Н. Паганіні для скрипки соло» в обробці для симфонічного оркестру. Композитор також не оминув увагою й кіно та театральні жанри.

Як відомо, М. Скорик брав участь в створенні таких кінострічок, як «Тіні забутих предків» С. Параджанова за твором М. Коцюбинського, «Високий перевал» І. Денисенка [3]. Не останнє місце, у свою чергу, займає і його співпраця з драматичним театром. М. Скорик брав участь в якості композитора в багатьох постановках. Яскравими прикладами слугують наступні вистави: «Пам’ять серця» О. Корнійчука, «Волинщик з Стракониць» Й. Тила, «Перстень $з$ діамантами» О. Левади, «І змовкли птахи» I. Шамякіна, «Каса маре» I. Друце. Окремо слід зазначити, що вони були здійснені в одному театрі - iм. I. Франка за відносно короткий період: кінець 60-70-х років XX ст. Географія творчих напрацювань композитора не обмежується театрами Києва та кіностудією ім. Довженка, а пролягає до Одеської, Ялтинської кіностудій, театрів Львова, Харкова та ін.

Для кращого розуміння проаналізованого матеріалу автором статті пропонується узагальнено-систематизуюча характеристика 3 подальшим більш конкретним розглядом найбільш яскравих прикладів 
з музично-театральних робіт кожного з вищеназваних композиторів окремо.

Аналіз організований за наступними параметрами:

1. Масштаб, під яким розуміється загальна кількість композиції.

M. Скорик: «Каса маре» - 23 номери; «Перстень 3 діамантом» 30 номерів; «І змовкли птахи» - 24 номери; «Волинщик із Стракониць» - 25 номерів; «Пам'ять серця» -16 номерів;

В. Рождественський: «Свічене весілля» - 40 номерів.

I. Шамо: «У неділю рано зілля копала» - 22 номери; «Макбет» 38 номерів.

2. Програмність. У зв'язку з відсутністю сценарію вищеназваних вистав даний параметр (незалежно від ступеня наявності) виступає орієнтиром їх приблизного місцезнаходження в загальнодраматургічній дії.

M. Скорик: «Каса маре», «Перстень $з$ діамантом» та «І змовкли птахи» - опосередкована; «Волинщик із Стракониць» та «Пам'ять серця» - наявна.

В Рождественський: «Свічене весілля» - наявна.

I. Шамо: «У неділю рано зілля копала» та «Макбет» - опосередкована, наявна.

3. Жанрово-інтонаційні джерела. Під цим параметром маються на увазі витоки тематичного матеріалу, на якому побудовано номери з вище перелічених вистав, оскільки за образно-сюжетною спрямованістю вони всі репрезентують найрізноманітніші мізансцени. На основі результатів первісного аналізу можна побачити, що разом із традиційними композиторськими прийомами авторами залучались й на той час авангардні техніки, зокрема алеаторика, кластерна техніка або монотембровість (тембровий мінімалізм) при створенні звукозображальних ефектів.

M. Скорик: «Каса маре» - народнопісенні та народно-танцювальні джерела; «Перстень з діамантом» - звукозображальність, пісенність; «І змовкли птахи» - звукозображальність, пісенність, танцювальність; «Волинщик із Стракониць» - народнопісенні та народно-танцювальні джерела; «Пам’ять серця» - звукозображальність, народна танцювальність.

B. Рождественський: «Свічене весілля» - фольклорність, пісенність, танцювальність, драматизм.

I. Шамо: «У неділю рано зілля копала» - фольклорність (жанр коломийки), танцювальність; «Макбет» - звукозображальність (авангардні ознаки), драматизм. 
4. Склад. Цей параметр характеризується через якість (темброва характеристика) та кількість інструментарію, задіяного в тому чи іншому номері. Через різноманітність інструментальних рішень, прийнятих композиторами у створенні музичного оформлення, даний параметр надає чітке уявлення про принципи оркестровки в тій чи іншій ситуації.

М. Скорик:

«Каса маре» - великий симфонічний оркестр парного складу 3 додаванням цимбал, баяна, електрогітари, бас-гітари.

«Перстень з діамантом» - флейта, гобой, кларнет, валторни-3, труби-2, І скрипки, II скрипки, альти, віолончелі, контрабаси, іоніка, табл, литаври.

«I змовкли птахи» - флейта, гобой, фагот, валторни-4, труби-2, литаври, перкусія, I скрипки, II скрипки, альти, віолончелі, контрабас, гітара, бас-гітара, вібрафон, іоніка.

«Волинщик із Стракониць» - великий симфонічним оркестр парного складу з додаванням акордеона, іоніки, перкусії, гітари.

«Пам'ять серця» - флейта, гобой, кларнет, валторни-2, труби-2, тромбон, I скрипки, II скрипки, альти, віолончелі, контрабаси, іоніка, литаври, фортепіано, електрогітара, бас-гітара.

В. П. Рождественський: «Свічене весілля» - великий симфонічний оркестр парного складу.

\section{I. Шамо:}

«У неділю рано зілля копала» - великий симфонічний оркестр парного складу.

«Макбет» - великий симфонічний оркестр парного складу з додаванням електрооргана, електрогітари, фортепіано, іоніки.

5. Композиційні функції. Цей параметр відображає роль кожного з вибраних номерів по відношенню до конкретної сценічної дії. Зазначені функції репрезентовано у чотирьох варіантах, що яскраво показує варіантність авторських підходів при створенні музики до драматичних вистав.

M. Скорик:

«Каса маре» - супровід, музичне випередження образу.

«Перстень $з$ діамантом» - супровід, музична характеристика образу. «І змовкли птахи» - образоутворююча та семантична функція, супровід.

«Волинщик із Стракониць» - супровід, музичне випередження образу, музична характеристика образу. 
«Пам'ять серця» - музичне випередження образу, супровід.

В. Рождественський:

«Свічене весілля» - супровід, музична характеристика образу.

I. Шамо:

«У неділю рано зілля копала» - супровід, музична характеристика образу.

«Макбет» - супровід, образоутворююча та семантична функція, музичне випередження образу.

6. Функції оркестрових груп. Інформація, яка закладена в цьому параметрі, безпосередньо пов'язана з інструментальною складовою, що трактується як один з базових компонентів стильової системи композиторів. Розгляд функцій проводився як по окремих групах повного симфонічного оркестру парного складу, так й відносно спеціально залучених інструментів із специфічним тембром. За допомогою аналізу обраних композицій за цим параметром можна отримати уяву про різні варіанти використання інструментів в музиці до драматичних вистав I. Шамо, В. Рождественського, М. Скорика.

М. Скорик:

«Каса маре». Дерев’яні духові: акомпонуюча функція. Мідні духові: акомпонуюча. Струнні: солююча, акомпонуюча. Ударні: солююча, акомпонуюча. Інші: електроорган, гітара, бас-гітара, фортепіано, іоніка, баян, акордеон, цимбали - солююча та акомпонуюча функції.

«Перстень $з$ діамантом». Дерев'яні духові: солююча, акомпонуюча. Мідні духові: акомпонуюча. Струнні: акомпонуюча. Ударні: акомпонуюча. Інші: електроорган, гітара, бас-гітара, фортепіано, іоніка, баян, акордеон, цимбали - акомпонуюча функція.

«І змовкли птахи». Дерев’яні духові: створення гармонічного шару, солююча. Мідні духові: акомпонуюча. Струнні: акомпонуюча. Ударні: акомпонуюча. Інші: електроорган, гітара, бас-гітара, фортепіано, іоніка, баян, акордеон, цимбали - акомпонуюча функція.

«Волинщик із Стракониць». Дерев'яні духові: солююча, акомпонуюча. Мідні духові: солююча, акомпонуюча. Струнні: солююча, акомпонуюча. Ударні: акомпонуюча. Інші: електроорган, гітара, басгітара, фортепіано, іоніка, баян, акордеон, цимбали - солююча та акомпонуюча функції.

«Пам’ять серця». Дерев'яні духові: акомпонуюча функція. Мідні духові: акомпонуюча. Струнні: солююча, створення гармонічного шару. Ударні: акомпонуюча. Інші: електроорган, гітара, бас-гітара, фортепіано, іоніка, баян, акордеон, цимбали - акомпонуюча. 


\section{В. Рождественський:}

«Свічене весілля». Дерев'яні духові: солююча та акомпонуюча функції. Мідні духові: солююча, акомпонуюча. Струнні: солююча, акомпонуюча. Ударні: акомпонуюча.

\section{I. Шамо:}

«У неділю рано зілля копала». Дерев’яні духові: солююча та акомпонуюча функції. Мідні духові: акомпонуюча. Струнні: солююча, акомпонуюча. Ударні: акомпонуюча.

«Макбет». Дерев'яні духові: солююча та акомпонуюча функції. Мідні духові: солююча, акомпонуюча. Струнні: солююча, акомпонуюча. Ударні: акомпонуюча. Інші: електроорган, гітара, бас-гітара, фортепіано, іоніка, баян, акордеон, цимбали - акомпанемент, створення гармонічного шару.

Яскравим прикладом інструментального стилю В. Рождественського виступає історична драма «Свічене весілля» I. Кочерги, постановка якої мала місце в театрі ім. І. Франка в середині $60-$ х років XX ст. Музика відіграє дуже важливу роль в цій виставі, про що свідчить, зокрема, кількість номерів партитури - 40 номерів.

Партитура вистави «Свічене весілля» досить традиційна для стилю В. Рождественського тим, що включає увесь звичний оркестровий інструментарій. В його використанні композитор спирається на сталі традиції українського музично-драматичного театру, зокрема - він віддає перевагу певним групам в сольному музикуванні. 3 іншого боку, важливою функцією оркестру була підтримка співаків і саме концентрована «однотемброва маса» сприяла цьому як найкраще. Вона ж виглядала найбільш доцільною і в інструментальних номерах репрезентативного (вступи, фінали) та танцювального характеру. Таке становище зберігало свою актуальність тривалий час, особливо у виставах на історичну тему, де оркестрова «маса» сприймалась як повністю зрозумілий і природний аналог зовнішній дії (зокрема в «масових» сценах). Композитор кожну з груп інструментів чітко визначав з точки зору семантики й пов'язував з різними сферами образності. Найбільш показовими в цьому відношенні здаються мідні духові та струнні інструменти. Перші з них є яскравими репрезентантами сфери драматизму, активної дії, конфлікту. Підтвердження саме цієї ролі знаходимо в таких номерах, як «Поява Воєводи», «Вихід Воєводи», «Тост Воєводи», «Сурма». В ліричних сценах на передній план виходять струнні інструменти. Така семантична «спеціалізація» інструментів повністю узгоджується з роллю музики в театрі, тобто її 
призначенням - посилення образної сторони сценічної дії для максимальної змістовно-смислової рельєфності. Тембральні властивості інструментів, судячи з творчої спадщини, мали індивідуалізувати певний змістовний нюанс, важливий саме для тої чи іншої драматургічної сцени.

Яскравими прикладами інструментального стилю I. Шамо виступають такі номери, як «Відьми» з вистави «Макбет» В. Шекспіра та «Пісня Маври» 3 «У неділю рано зілля копала» О. Кобилянської. Номер «Відьми» виступає в ролі звукозображальної замальовки. Її стильовою особливістю постає алеаторика, що є досить незвичним для творчості українських композиторів тих часів, оскільки вона належала до видів авангардної техніки, що зовсім не віталося у тогочасній вітчизняній практиці. Для даного номера I. Шамо залишає монотембровий склад струнних інструментів, дещо «висвітлений» арфою. Протягом 8 тактів всі інструменти виконують однотипні мелодичні рухи - в межах приблизно 1/5 октави у зручному для кожного з виконавців регістрі, починаючи з найнижчого звуку, який можливий для того чи іншого музичного інструменту. Метричні умови ледь намічені, оскільки за авторською вказівкою гамоподібні пасажі поновлюються в кожному наступному 4-дольному такті. Ніяких додаткових позначень відносно ритмічних тривалостей різновиду глісандо (по хроматизмах або по діатоніці) немає, що свідчить про намагання композитора намітити «зміст» номера, лише в самих загальних рисах створивши враження страшного, хаотичного, невпинного демонічного шквалу.

«Пісня Маври» 3 вистави О. Кобилянської «У неділю рано зілля копала» має не стільки розгорнутий вигляд, типовий для пісенного жанру, скільки ледь намічений «ескіз» з залучанням ліричної за характером мелодики, побудованої в квінтовому діапазоні з переважанням довгих тривалостей та плавного руху тематичної лінії з відсутністю різких метро-ритмічних змін. Доречним виступає й підбір інструментарію. Тембральне поєднання струнних разом з кларнетом та фаготом являється досить поширеним для такого роду ситуацій (створення ліричного образу та характеристика відповідної атмосфери) в українській музиці. В подальшому супровід вокалу присутній виключно в партіях струнних інструментів, за фактурою нагадуючи своєрідний «кант». Тобто скрипки дублюють партію вокаліста, II скрипки разом з альтами та віолончелями створюють акомпонуючий шар, а контрабаси утворюють традиційну гармонічну основу. 
При ознайомленні з театральною музикою М. Скорика, звертає на себе увагу значне розширення інструментального складу порівняно 3 50-60-ми роками XX ст. Основу цього оркестру складають традиційні для оперної та симфонічної практики представники, що об'єднані у кілька основних груп: дерев'яні та мідні духові інструменти, струнні та ударні. Разом із тим М. Скорик в кожній з вистав пропонує варіантний склад цих базових груп. Зокрема у виставі «Перстень 3 діамантами» дерев'яні духові репрезентовані флейтою, гобоєм, кларнетом; мідні - валторнами та трубами. Традиційний струнний квінтет кількісно виглядає так: перших скрипок - 4; других скрипок -3 ; альтів -2 ; віолончелей -2 ; контрабасів -2 . Ударні представлено литаврами та таблом. Взагалі, продивляючи музичні партитури вищеназваних вистав, слід відмітити стосовно ударного інструментарію наявність гармонічного поєднання, так би мовити, «академічного» інструментарію типу литавр, тамбуріна, cassa, piati, разом з «естрадними» по типу вібрафона та батареї.

Також М. Скорик «оновив» свою оркестрову палітру шляхом залучення естрадних інструментів: іоніки, гітари, бас-гітари, ритм-гітари. Причому намітилось декілька варіантів їх використання. Один з них полягає у використанні в суто «своєму середовищі» (тобто естраднопопулярному): як в № 3 та № 9 з вистави «І змовкли птахи». А інший - у поєднанні з традиційними акустичними інструментами. Яскравими зразками такого поєднання представляються № 6 з вистави «Перстень $з$ діамантами», репрезентований скрипкою в дуеті з іонікою, та № 11 з вистави «Волинщик з Стракониць», який, у свою чергу, виконуваний саmpanelli та іонікою. Інколи «естрадні» інструменти виходять на перший план або, навпаки, використовуються лише як своєрідна барва, своєрідний «відтінок» у тембральній палітрі загального оркестрового звучання.

Крім того, досить часто М. Скорик звертається до баяна. Цей інструмент залучається автором для супроводу, як, наприклад, у вокально-інструментальному номері «Пісня Беранже» 3 вистави «Пам'ять серця». Також він може використовуватись як самостійно (наприклад, № 2 з «Каса маре»), так і в рамках різних ансамблів (наприклад, «Полька на ярмарку» з вистави «Волинщик з Стракониць»).

Як вже було сказано раніше, номінально оркестр тотожний симфонічному, але за кількістю конкретних інструментів він може не збігалися з відомими його типами, наприклад - парним або потрійним. Навпаки, партитура кожної нової роботи М. Скорика дає різні при- 
клади оновлення в цьому відношенні, наприклад: чотири валторни в № 4 з вистави «І змовкли птахи» та одна валторна в № 7 у тому ж творі; гобой в п'єсі «I змовкли птахи» і він же в парі з спорідненим інструментом - англійським ріжком у виставі «Волинщик з Стракониць»; в п'єсі «Каса маре» група дерев'яних використовується без фагота або, навпаки, М. Скорик залучає два фаготи в «І змовкли птахи».

Досить оригінальна ситуація виникає при розгляді питання співвідношення груп. Зовсім не обов'язково всі вони мають бути присутні в кожному з номерів тієї чи іншої вистави. Наприклад в № 113 вистави «І змовкли птахи» представлено дві з чотирьох основних груп інструментів (а саме дерев’яні духові та струнні), а в № 12 тієї ж вИстави на місці дерев'яних з'являються мідні духові.

Висновки. Таким чином, на основі проаналізованої нами театральної музики В. Рождественського, І. Шамо та М. Скорика можна стверджувати, що ці композитори проявили себе як майстри з чітко визначеними власними інструментальними стилями. Стрижнем цього слід вважати постійне намагання індивідуалізувати, перш за все, виконавський склад. Базою для того виступає великий симфонічний оркестр парного складу, «адаптований» для потреб і можливостей драматичного театру: мається на увазі значно менша кількість колективу, але зі збереженням усіх пропорцій оркестру такого типу. Це відповідало традиціям тогочасної української практики i, разом з тим, дозволяло створювати музичну «складову», близьку до симфонічного та оперного жанрів. Одночасно можна прослідкувати певну тенденцію до «оновлення» тембрального забарвлення інструментарію через залучення гітари, електрогітари, бас-гітари, електрооргана та інших інструментів у процесі еволюції театрально-драматичного жанру. Якщо у «Свіченому весіллі» В. Рождественського репрезентовано традиційний оркестр, то вже під впливом часу у І. Шамо, а особливо в музиці М. Скорика мають велике значення вищеназвані електроінструменти.

Підсумовуючи вищесказане, зазначимо важливість вивчення місця та ролі оркестру в музиці до драматичних вистав у творчому доробку В. Рождественського, І. Шамо та М. Скорика. Також звернемо увагу на специфічність використання інструментарію в драматичному театрі у порівнянні з творами цих композиторів в оперному та філармонічних жанрах. 


\section{СПИСОК ЛІТЕРАТУРИ}

1. Вергелис О. Жестокий романс.ZN. UA.№ 17, 14 мая 2011 г.. с.17.

2. Глумов А. Музыка в русском драматическом театре: Ист. Оч. М.: Гос. муз. изд., 1955. 481 с.,ил.

3. Кияновська Л. Мирослав Скорик: творчий портрет композитора в дзеркалі епохи. Л.: Сполом, 1998. 208 с.

4. Красильникова О. Історія українського театру XX сторіччя К.: Либідь, 1999. 208 с., іл.

5. Кузякина Н. Лесь Курбас: статьи и воспоминания о Л. Курбасе. Литературное наследие. М.: Искусство, 1988. 463 с., 28 л.ил.

6. Невенчаная Т. Игорь Шамо. К.: Музична Україна, 1982. 88c.

7. Муха А. И. Союз композиторов Украины. Справочник. К.: Музична Україна, 1978. 264 с., портр.

8. Скрипник Г. Історія українського театру: У 3 т. Т.2 (1900-1945). К.: НАН України, ІМФЕ ім. М. Т. Рильського, 2009. 876 с., іл.

9. Станишевский Ю. Музыкальный театр // Театральная энциклопедия: В 5 т. Т.5 М.: Советская энциклопедия, 1967. С. 361-364.

\section{REFERENCES}

1. Vergelis, O. (2011). Cruel romance. ZN. UA.№ 17, on May 14, 2011 [in Russian].

2. Glumov, A. (1955). Music in the Russian drama theater. M.: State. muses. prod. [in Russian].

3. Kiyanovska, L. (1998). Myroslav Skoryk: creative portrait of the composer in the mirror of the era. L.: Spolom [in Ukrainian].

4. Krasilnikova, O. (1999). History of the Ukrainian theater of the XX century. K.: Lybid [in Ukrainian].

5. Kuzyakina, N. (1988). Les Kurbas: Articles and memories of L. Kurbas. Literary heritage. M.: Art [in Russian].

6. Nevenchana, T. (1982). Igor Shamo. K Muzichna Ukraina [in Russian].

7. Muha, A. (1978). Union of composers of Ukraine. Reference book. K.: Muzichna Ukraina [in Russian].

8. Skrypnyk, G. (2009). History of the Ukrainian theater: In 3 Vol. - (Vol.2 (1900-1945)) K.: NAS of Ukraine, IMF im. M. T. Rylsky [in Ukrainian].

9. Stanishevsky, Yu. (1967). Musical Theater. Theatrical Encyclopedia: At 5 vols. (Vol.5), (pp. 361-364). M.: Soviet Encyclopedia [in Russian].

Стаття надійшла до редакції 22.06.2016

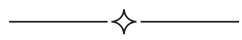

